\title{
Obniżenie policjantowi nagrody rocznej w przypadku popełnienia przewinienia dyscyplinarnego stwierdzonego w prawomocnie zakończonym postępowaniu dyscyplinarnym
}

\section{Wprowadzenie}

Jak wynika wprost z art. 1 ust. 1 Ustawy z dnia 6 kwietnia 1990 r. o Policji ${ }^{1}$, Policja jest umundurowaną i uzbrojoną formacją służącą społeczeństwu i przeznaczoną do ochrony bezpieczeństwa ludzi oraz do utrzymywania bezpieczeństwa i porządku publicznego. Jest to główne zadanie tej organizacji. Właściwa realizacja wytyczonych Policji zadań wymaga jednak zapewnienia rzeczywistych ich wykonawców. Są nimi członkowie tej formacji, tj. funkcjonariusze. To właśnie wykonywane przez nich czynności świadczą w szerszym zakresie o właściwej realizacji ustawowych zadań tej organizacji. Suma bowiem zadań poszczególnych policjantów stanowi o wykonywaniu zadań danej komórki organizacyjnej jednostki Policji. Z kolei suma zadań wszystkich komórek świadczy o wykonywaniu zadań przez tę jednostkę Policji. Zadania wykonywane przez wszystkie jednostki organizacyjne Policji stanowią potwierdzenie właściwej realizacji zadań przez całą formację, tj. Policję.

Służba publiczna, bo w takim kontekście należy rozważać służbę w Policji, zdeterminowała ustawodawcę do uregulowania w odrębny i szczególny sposób kwestii zatrudnienia funkcjonariuszy w tej formacji.

* Paweł Gacek, dr, Komenda Główna Policji, e-mail: p.gacek@wp.pl, http://orcid. org/0000-0001-6365-3146.

${ }^{1}$ Tekst jedn. Dz.U. 2020, poz. 360 ze zm., dalej „ustawa o Policji”. 
Więź prawna, jaką jest stosunek służbowy, ma charakter wyłącznie administracyjnoprawny ${ }^{2}$. Jest nią mianowanie. Chociaż wymienione pojęcie jest tożsame z mianowaniem, o którym mowa w art. 76 Ustawy z dnia 26 czerwca 1974 r. Kodeks pracy ${ }^{3}$, to nie budzi wątpliwości, że instytucje te (zawarte w ustawie o Policji oraz w k.p.) stanowią dwie odrębne konstrukcje prawne. Mianowanie, o którym mowa w k.p., wiąże się z nawiązaniem stosunku pracy, w stosunku służbowym natomiast tego elementu brakuje.

Charakterystyczną cechą stosunku służbowego jest wzmożona dyspozycyjność funkcjonariusza co do miejsca, czasu oraz rodzaju wykonywanych czynności, podporządkowanie wobec przełożonych, tj. wobec bezpośredniego przełożonego, przełożonego właściwego w sprawach osobowych i innych przełożonych. Elementem, który umożliwia egzekwowanie od policjanta jego obowiązków, a zatem gwarantuje zachowanie pełnej dyspozycyjności i podporządkowania, jest odpowiedzialność o charakterze dyscyplinarnym i porządkowym. Jak słusznie podkreśla się w doktrynie, „[j] ]ednym ze skutków nawiązania stosunku służby jest powstanie po stronie przełożonego służbowego policjanta daleko posuniętego władztwa administracyjnego - władztwa służbowego"4. Władztwo to umożliwia wydawanie policjantowi wiążących go rozkazów i poleceń służbowych, których niewykonanie lub niewłaściwe wykonanie zabezpieczone jest sankcją o charakterze dyscyplinarnym.

Pełna dyspozycyjność i podporządkowanie funkcjonariusza jest tym elementem, który zasadniczo odróżnia i odgranicza stosunek służbowy

${ }^{2}$ P. Gacek, Nawiązanie stosunku stużbowego z funkcjonariuszem Policji, „Administracja: Teoria, Dydaktyka, Praktyka" 2011, nr 2(23), s. 76 i n.; idem, Odwołanie od rozkazu personalnego, "Przegląd Policyjny” 2016, nr 3(123), s. 80; T. Hanausek i in., Prawo Policyjne. Komentarz, t. 1, pod red. S. Sagana, Katowice 1992, s. 69; J. Kacprzak, Stosunki stużbowe $w$ formacjach zmilitaryzowanych - charakter prawny, ochrona sądowa, "Przegląd Policyjny" 1994, nr 1(33), s. 97; M. Liwo, Status służb mundurowych i funkcjonariuszy w nich zatrudnionych, Warszawa 2013, s. 311 i n.; W. Maciejko, A. Korcz-Maciejko, Postępowanie w sprawach osobowych w Policji, Wrocław 2010, s. 20; P. Szustakiewicz, Istota stosunku stużbowego, w: W. Maciejko, P. Szustakiewicz, Stosunek stużbowy w formacjach mundurowych, Legalis 2016; T. Szankin, Stużba w Policji, w: Prawo policyjne, pod red. M. Czuryk, M. Karpiuka, J. Kostrubca, K. Orzeszyna, Warszawa 2014, s. 200 i n. Przeciwne stanowisko prezentuje T. Hanausek, Ustawa o Policji. Komentarz, Kraków 1996, s. 72.

${ }^{3}$ Tekst jedn. Dz.U. 2020, poz. 1320, dalej „k.p.”.

${ }^{4}$ W. Maciejko, Osobowe prawo administracyjne, Warszawa 2008, s. 156; W. Maciejko, M. Rojewski, A. Suławko-Karetko, Prawo administracyjne. Zarys wykładu części szczególnej, Warszawa 2011, s. 141. 
z mianowania od służbowego stosunku pracy z mianowania. Należy zgodzić się z T. Zielińskim, że nasilenie pierwiastków władczych w stosunku służbowym jest tak wielkie, że reżim prawa pracy musiał ustąpić reżimowi prawa administracyjnego ${ }^{5}$. Wobec tego służba nie może być traktowana na równi z inną pracą najemną. Jak zaznacza Naczelny Sąd Administracyjny (NSA) w wyroku z 27 sierpnia 2013 r. ${ }^{6}$ "[s]zczególny charakter służby publicznej funkcjonariuszy Policji umożliwia odmienne i bardziej rygorystyczne, niż w wypadku pozostałych zawodów i funkcji, ukształtowanie statusu służbowego". Administracyjnoprawny charakter tej więzi prawnej umożliwia zatem jednostronne i władcze jej kształtowanie przez podmiot zatrudniający, tj. przełożonego właściwego w sprawach osobowych. Policjant nie uczestniczy w żaden sposób w określeniu warunków pełnienia służby. Może zaproponowane warunki przyjąć w całości lub je odrzucić, ale tym samym stosunek ten nie będzie mógł zostać nawiązany. Istotne jest jednak to, że służba ma charakter dobrowolny. Egzekwowanie przez przełożonego obowiązków wynikających z treści stosunku służbowego musi być więc poprzedzone zgodą osoby na poddanie się rygorom wynikającym z charakteru tej więzi prawnej. Należy zatem wskazać, że policjant, co do zasady, nie podlega reżimowi wynikającemu z przepisów prawa pracy, bo nie jest pracownikiem $w$ rozumieniu art. 2 k.p., a przełożony właściwy w sprawach osobowych nie jest pracodawca w rozumieniu art. 3 k.p. Policjant nie wykonuje pracy, ale pełni służbę. Nie otrzymuje wynagrodzenia, ale uposażenie, które rekompensuje permanentną dyspozycyjność i obowiązek poświęcenia się w służbie. Składa on bowiem ślubowanie. Jak zaznacza judykatura, "Zobowiązanie to nie jest tylko deklaracja, ale oznacza, że «policjant zobowiązany jest dochować obowiązków wynikających z roty złożonego ślubowania»"

Służba w Policji rodzi wiele obowiązków, którym funkcjonariusz musi sprostać, obowiązków nieznanych innym grupom zawodowym, których podstawą zatrudnienia jest stosunek pracy. Jednakże zwiększona dyspozycyjność, podporządkowanie i gotowość do poświęcenia

${ }^{5}$ T. Zieliński, Stosunek prawa pracy do prawa administracyjnego, Warszawa 1977, s. 181.

${ }^{6}$ Wyrok NSA z 27 VIII 2013 r., sygn. I OSK 1902/12, Legalis nr 1924883. Orzeczenie dotyczyło kwestii odpowiedzialności dyscyplinarnej funkcjonariusza Policji, lecz można to stanowisko odnieść także do kwestii samego stosunku służbowego.

${ }^{7}$ Wyrok NSA z 10 II 2012 r., sygn. I OSK 1056/11, Legalis nr 448397; wyrok NSA z 24 I 2007 r., sygn. I OSK 664/06, Legalis nr 657705; B. Opaliński, Uwagi do art. 27, w: B. Opaliński, M. Rogalski, P. Szustakiewicz, Ustawa o Policji. Komentarz, wyd. 2, Warszawa 2020. 
się w służbie jest rekompensowana funkcjonariuszom licznymi przywilejami ustanowionymi w ustawie o Policji. Jednym z nich jest prawo do nagrody rocznej. Nie sposób odnieść się do wszystkich aspektów tego zagadnienia $\mathrm{w}$ ramach jednego opracowania. Stąd też dalsze rozważania zostaną skoncentrowane wyłącznie na kwestiach związanych z podstawą obligującą do obniżenia nagrody rocznej, zamieszczoną w art. 110 ust. 5 pkt 2 ustawy o Policji. Pragmatyka służbowa przewiduje enumeratywnie wskazane w art. 110 ust. 5 ustawy o Policji przypadki, gdy zachodzi konieczność pomniejszenia policjantowi przysługującej mu nagrody rocznej. Problematyka ta nie została dotąd szerzej omówiona w literaturze przedmiotu, a stanowi, jak się wydaje, istotne zagadnienie zarówno dla organów Policji zobligowanych do stosowania przepisów pragmatyki służbowej, jak i samych policjantów, których kwestia ta może dotyczyć. Przewinienie dyscyplinarne stwierdzone w prawomocnie zakończonym postępowaniu dyscyplinarnym jest najczęstszą przyczyną skutkującą koniecznością obniżenia nagrody rocznej funkcjonariuszowi Policji ${ }^{8}$. Wobec tego konieczne jest ustalenie, w jakim momencie materializuje się przesłanka, o której mowa w art. 110 ust. 5 pkt 2 ustawy o Policji, a także jakie konsekwencje może wywołać w sferze finansowej funkcjonariusza Policji. Zagadnienia te wypełnią zasadniczą część niniejszego opracowania. Jednakże rozważania w tym zakresie muszą zostać poprzedzone omówieniem problematyki związanej z instytucją nagrody rocznej, jej obniżenie może bowiem nastąpić,

${ }^{8}$ Dodać jednak należy, że art. 1 pkt 15 Ustawy z dnia 14 VIII 2020 r. o szczególnych rozwiązaniach dotyczących wsparcia służb mundurowych nadzorowanych przez ministra właściwego do spraw wewnętrznych, o zmianie ustawy o Służbie Więziennej oraz niektórych innych ustaw (Dz.U. 2020, poz. 1610) zmienił dotychczasowe brzmienie art. 110 ust. 5 pkt 2 ustawy o Policji. Przepis ten w poprzednim brzmieniu zobowiązywał do obniżenia nagrody rocznej wyłącznie w sytuacji popełnienia przez policjanta przewinienia dyscyplinarnego polegającego na naruszeniu dyscypliny służbowej, stwierdzonego w prawomocnie zakończonym postępowaniu dyscyplinarnym. Nie obejmował natomiast przypadków przewinienia dyscyplinarnego polegającego na nieprzestrzeganiu zasad etyki zawodowej. Wprowadzona zmiana obliguje do obniżenia nagrody rocznej $\mathrm{w}$ sytuacji popełnienia przewinienia dyscyplinarnego stwierdzonego $\mathrm{w}$ prawomocnie zakończonym postępowaniu dyscyplinarnym, i to niezależnie od tego, czy polega na naruszeniu dyscypliny służbowej czy też na nieprzestrzeganiu zasad etyki zawodowej. Wymieniona ustawa wchodzi w życie z dniem 1 X 2020 r. (art. 48 ustawy o szczególnych rozwiązaniach dotyczących wsparcia służb mundurowych nadzorowanych przez ministra właściwego do spraw wewnętrznych, o zmianie ustawy o Służbie Więziennej oraz niektórych innych ustaw). Wobec tego, w uzupełnieniu, należy zastrzec, że dotychczas najczęstszą przyczyną obniżenia nagrody rocznej były wyłącznie te przewinienia dyscyplinarne, które polegały na naruszeniu dyscypliny służbowej. 
jeśli uprzednio policjant nabył do niej prawo. Kwestią wstępną jest więc ustalenie, czym w istocie jest prawo do nagrody rocznej i jakie warunki muszą być spełnione, aby policjant mógł to prawo nabyć.

\section{Instytucja nagrody rocznej}

Przystępując do omówienia zagadnień związanych z instytucją nagrody rocznej, należy skoncentrować uwagę na przepisie art. 110 ustawy o Policji, to on bowiem statuuje ogólne zasady jej przyznawania, obniżania oraz pozbawiania prawa do niej ${ }^{9}$. Jak wynika wprost $\mathrm{z}$ art. 110 ust. 1 ustawy o Policji, policjantowi za służbę pełnioną w danym roku kalendarzowym przysługuje nagroda roczna w wysokości 1/12 uposażenia otrzymanego w roku kalendarzowym, za który nagroda przysługuje. Nagroda roczna przysługuje, jeżeli policjant $\mathrm{w}$ danym roku kalendarzowym pełnił służbę przez okres co najmniej 6 miesięcy kalendarzowych. Okresy służby krótsze od miesiąca kalendarzowego sumuje się, przyjmując, że każde 30 dni służby stanowi pełny miesiąc kalendarzowy (art. 110 ust. 3 ustawy o Policji). Bezcelowe byłoby odniesienie się szczegółowo do wszystkich zasad związanych z prawem do nagrody rocznej ${ }^{10}$. Należy jedynie zaznaczyć, że zasadą jest, iż nagroda roczna przysługuje policjantowi, który faktycznie pełnił służbę ${ }^{11} \mathrm{w}$ danym roku kalendarzowym,

${ }^{9}$ Wyrok Wojewódzkiego Sądu Administracyjnego (WSA) w Bydgoszczy z 17 X 2018 r., sygn. II SA/Bd 421/18, Legalis nr 1864777; wyrok WSA w Krakowie z 23 VIII 2017 r., sygn. III SA/Kr 622/17, Legalis nr 1665440; W. Kotowski, Ustawa o Policji. Komentarz, Warszawa 2008, s. 593.

${ }^{10} \mathrm{~W}$ art. 110 ust. 3a ustawy o Policji wskazane są okresy niewykonywania przez policjanta zadań służbowych, które nie mogą zostać zaliczone do okresu, o którym mowa w art. 110 ust. 3 ustawy o Policji, chyba że wystąpią okoliczności, o których mowa w art. 110 ust. $3 b$ ustawy o Policji - z wyjątkiem sytuacji przewidzianej w art. 110 ust. 3c ustawy o Policji. Natomiast art. 110 ust. 4 ustawy o Policji statuuje przypadki, które uprawniają policjanta do nabycia prawa do nagrody rocznej mimo braku wymaganego okresu służby w danym roku kalendarzowym w wymiarze, o którym mowa w art. 110 ust. 3 ustawy o Policji.

11 "[...] policjantowi przysługuje nagroda roczna za okres służby faktycznie pełnionej w danym roku kalendarzowym" (wyrok WSA w Warszawie z 28 VII 2010 r., sygn. II SA/Wa 619/10, Legalis nr 266629); w tym samym tonie wyrok WSA w Szczecinie z 16 XI 2011 r., sygn. II SA/Sz 901/11, Legalis nr 396742, oraz wyrok WSA w Szczecinie z 26 I 2011 r., sygn. II SA/Sz 785/10, Legalis nr 526363. Z kolei I. Sierocka wskazuje, że prawo to uzależnione jest od wykonywania przez policjanta obowiązków służbowych w danym roku kalendarzowym (I. Sierocka, Nagrody roczne funkcjonariuszy Policji , "Monitor Prawa Pracy" 2012, nr 3, s. 128). 
w wymaganym okresie. Okres ten, jak słusznie wskazuje judykatura, nie może być krótszy niż 6 miesięcy ${ }^{12}$, przy czym należy zastrzec, że nie chodzi w tym przypadku o służbę pełnioną nieprzerwanie przez 6 miesięcy w roku kalendarzowym, za który nagroda ma być przyznana, ale o łączny okres służby w całym roku kalendarzowym. Nie może być on krótszy od okresu wskazanego w art. 110 ust. 3 ustawy o Policji, gdyż jest to minimalny okres warunkujący nabycie prawa do nagrody rocznej. Od tak ustanowionej zasady przewidziano wyjątki, które - jak zaznacza T. Kotowski - uzasadnione są względami służbowymi i społecznymi ${ }^{13}$.

Celem nagrody rocznej jest motywacja tych funkcjonariuszy, którzy w danym roku kalendarzowym byli rzeczywistymi wykonawcami zadań służbowych ${ }^{14}$. Nabycie prawa do nagrody rocznej, a także jej wysokość zależne są bowiem od okresu pełnionej służby.

Istotne z punktu widzenia omawianej problematyki jest ustalenie punktu na osi czasowej, który materializuje to prawo. Ustalenie tego momentu pozwala nie tylko na przyznanie nagrody rocznej, ale też na jej obniżenie. Jeśli policjant nie nabył prawa do nagrody rocznej za dany rok kalendarzowy, bezprzedmiotowe byłoby uruchomienie mechanizmu, który obligowałby do jej obniżenia, nawet w sytuacji, w której zostałby spełniony warunek, o którym mowa w art. 110 ust. 5 pkt 2 ustawy o Policji, tj. zostałoby prawomocnie zakończone postępowanie dyscyplinarne, podczas którego stwierdzono by naruszenie przez policjanta dyscypliny służbowej lub nieprzestrzeganie zasad etyki zawodowej.

Co do zasady prawo do nagrody rocznej materializuje się po upływie roku kalendarzowego, w którym policjant pełnił służbę. Z treści art. 110 ust. 9 ustawy o Policji wynika natomiast, że wypłaca się ją do dnia 31 marca roku kalendarzowego następującego po roku, za który

\footnotetext{
12 Wyrok NSA z 17 V 2017 r., sygn. I OSK 3436/15, Legalis nr 1652050.

${ }^{13}$ W. Kotowski, Ustawa..., s. 593.

14 "Nagroda określona w omawianym przepisie ma charakter temporalno-motywacyjny. O temporalnym charakterze omawianej nagrody świadczy, że jest ona przyznawana co roku. Natomiast na motywacyjny charakter nagrody wskazuje, że jest ona przyznawana tylko tym policjantom, którzy pełnili służbę w sposób nienaganny" (B. Opaliński, M. Rogalski, P. Szustakiewicz, Uwagi do art. 110, w: Ustawa o Policji. Komentarz, Warszawa 2015); w tym samym tonie P. Szustakiewicz, Stosunki służbowe funkcjonariuszy stużb mundurowych $i$ żotnierzy zawodowych jako sprawa administracyjna, Warszawa 2012, s. 210 i n., a także "nagrodę roczną przyznaje się jako gratyfikację należną policjantowi z tytułu wypełnienia jego obowiązków służbowych w danym roku kalendarzowym" (wyrok WSA w Gliwicach z 11 II 2014 r., sygn. IV SA/Gl 424/13, Legalis nr 963053).
} 
nagroda przysługuje. Choć nie wynika to expressis verbis z powołanego przepisu, to nie może budzić wątpliwości, że tylko po upływie roku kalendarzowego, za który nagroda ma być przyznana, możliwe jest zsumowanie okresów pełnionej przez policjanta służby i ustalenie, czy został spełniony wymóg minimalnego jej pełnienia przez okres co najmniej 6 miesięcy, oczywiście z uwzględnieniem pozostałych przepisów całej regulacji odnoszących się do warunków, od których uzależnione jest nabycie prawa do nagrody rocznej. Tym samym ustalenie okoliczności, o których mowa, możliwe jest najwcześniej w pierwszym dniu roku kalendarzowego następującego po roku kalendarzowym, w którym funkcjonariusz pełnił służbę, za którą ma być mu przyznana nagroda roczna. Powołany art. 110 ust. 9 ustawy o Policji wskazuje natomiast maksymalny termin wypłaty nagrody rocznej. Wypłata jest czynnością materialno-techniczną ${ }^{15}$, ale bezsprzecznie musi ją poprzedzać czynność przyznania nagrody rocznej. Na podstawie wymienionego przepisu można zatem ustalić treść normy prawnej, która określa maksymalny termin zobowiązujący do przyznania nagrody rocznej. Przyznanie tej nagrody musi bowiem nastąpić do dnia 31 marca roku kalendarzowego następującego po roku, za który nagroda przysługuje. Nie ulega wątpliwości, że przyznanie nagrody rocznej i jej wypłata mogą nastąpić w tym samym dniu, a ostatnim dniem, w którym może to nastąpić, jest termin wskazany w art. 110 ust. 9 ustawy o Policji. Jest to zarazem ostatni dzień, w którym może być ona przyznana funkcjonariuszowi. Tym samym przyznanie policjantowi nagrody rocznej musi nastąpić w pierwszych trzech miesiącach roku kalendarzowego następującego po roku kalendarzowym, za który nagroda roczna ma być przyznana.

Wyjątek stanowi zwolnienie policjanta ze służby w Policji. Wówczas policjant może nabyć prawo do nagrody rocznej jeszcze w tym samym roku kalendarzowym, w którym pełnił służbę, a nie po upływie tego roku kalendarzowego. Zgodnie bowiem z art. 110 ust. 10 ustawy o Policji wypłata nagrody rocznej dla zwalnianego policjanta następuje w terminie 14 dni od dnia zwolnienia go ze służby w Policji. Oznacza to, że przyznanie tej nagrody może nastąpić najpóźniej w terminie 14 dni od dnia zwolnienia ze służby w Policji i w tym samym dniu winna być wypłacona. Najwcześniej prawo to materializuje się natomiast w dniu zwolnienia ze służby w Policji, tj. z upływem wskazanego w rozkazie

${ }^{15}$ Postanowienie WSA w Gliwicach z 13 IV 2015 r., sygn. IV SA/G1 309/15, Legalis nr 1279745; wyrok WSA w Warszawie z 12 III 2015 r., sygn. II SA/Wa 2152/14, Legalis nr 1383374. 
personalnym o zwolnieniu ze służby w Policji dnia jako dnia tego zwolnienia. Nie zwalnia to oczywiście, co do zasady, z obowiązku zweryfikowania, czy zwalniany policjant $\mathrm{w}$ danym roku kalendarzowym spełnił warunek co do minimum okresu pełnienia służby w tym roku (art. 110 ust. 3 ustawy o Policji), chyba że zaistniał przypadek, o którym mowa w art. 110 ust. 4 pkt 3 ustawy o Policji, tj. policjant został zwolniony ze służby w związku z nabyciem uprawnień do emerytury lub renty bądź na podstawie art. 41 ust. 2 pkt 6 lub 7 ustawy o Policji. Wówczas zgodnie z art. 110 ust. 4 ustawy o Policji nie stosuje się warunku, o którym mowa w art. 110 ust. 3 ustawy o Policji.

Drugim wyjątkiem jest śmierć policjanta albo jego zaginięcie. Zgodnie $\mathrm{z}$ art. 110 ust. 11 ustawy o Policji przepis art. 110 ust. 10 ustawy o Policji stosuje się odpowiednio. Przyznanie nagrody rocznej powinno nastąpić w dniu śmierci albo uznania policjanta za zaginionego, a najpóźniej w terminie 14 dni od tego dnia. W wymienionych przypadkach należną policjantowi nagrodę roczną wypłaca się małżonkowi, a w dalszej kolejności dzieciom oraz rodzicom uprawnionym do renty rodzinnej. W sytuacjach wymienionych $w$ art. 110 ust. 11 ustawy o Policji również konieczne jest uprzednie zbadanie, czy zmarły albo zaginiony policjant spełnił wymogi do nabycia tego prawa. Prawo do nagrody rocznej nie materializuje się ipso facto $\mathrm{w}$ związku ze śmiercią albo zaginięciem policjanta, ale w związku z ustaniem stosunku służbowego, które następuje wraz ze śmiercią albo zaginięciem policjanta ${ }^{16}$, pod warunkiem jednak spełnienia pozostałych wymogów, jakie pragmatyka służbowa przewiduje $\mathrm{w}$ tym zakresie.

Przepisy art. 110 ust. 12-15 ustawy o Policji określają podmioty uprawnione do przyznania nagrody rocznej. Ustawodawca posłużył się dwiema metodami. Pierwsza wskazuje na konkretny podmiot uprawniony w stosunku do policjantów zajmujących określone stanowiska służbowe. Jest nim minister właściwy do spraw wewnętrznych, który przyznaje nagrody roczne Komendantowi Głównemu Policji oraz jego

${ }^{16}$ Co prawda § 1 pkt 8 Rozporządzenia Ministra Spraw Wewnętrznych z 14 V 2013 r. w sprawie szczegółowych praw i obowiązków oraz przebiegu służby policjantów (Dz.U. 2020, poz. 113) wskazuje, że ustanie stosunku służbowego następuje, gdy dochodzi do jego rozwiązania w związku ze zwolnieniem policjanta ze służby lub z jego śmiercia, to nie może jednak budzić wątpliwości, że zaginięcie także wywołuje ten sam skutek. Stąd też M. Wieczorek postuluje de lege ferenda, aby zaginięcie policjanta również było podstawą wygaśnięcia stosunku służbowego wzorem innych pragmatyk służbowych (M. Wieczorek, Charakter prawny stosunków stużbowych funkcjonariuszy służb mundurowych, Toruń 2017, s. 291 i n.). 
zastępcom (art. 110 ust. 14 ustawy o Policji). Minister ten przyznaje również nagrodę roczną Komendantowi Biura Spraw Wewnętrznych Policji oraz jego zastępcom, na wniosek Inspektora Nadzoru Wewnętrznego (art. 110 ust. 15 in fine ustawy o Policji). Z kolei Komendant Główny Policji przyznaje nagrody roczne Komendantowi Centralnego Biura Śledczego Policji, dowódcy Centralnego Pododdziału Kontrterrorystycznego Policji „BOA", komendantom wojewódzkim Policji (Komendantowi Stołecznemu Policji), komendantom szkół policyjnych i ich zastępcom oraz rektorowi Wyższej Szkoły Policji w Szczytnie oraz osobie pełniącej w uczelni służb państwowych funkcję kierowniczą do spraw realizacji zadań uczelni, jako jednostki organizacyjnej właściwej służby (art. 110 ust. 15 zd. 1 ustawy o Policji). Jest to katalog wyczerpujący (numerus clausus).

Pozostałym funkcjonariuszom Policji nagrodę roczną przyznają przełożeni właściwi w sprawach mianowania policjantów na stanowiska służbowe, przenoszenia oraz zwalniania z tych stanowisk (art. 110 ust. 13 ustawy o Policji). W przypadku pełnienia przez policjanta w roku kalendarzowym służby w różnych jednostkach organizacyjnych Policji nagrodę roczną przyznaje się i wypłaca w jednostce, która była w danym roku ostatnim miejscem pełnienia przez niego służby (art. 110 ust. 12 ustawy o Policji). Przełożonym uprawnionym do przyznania nagrody rocznej jest więc przełożony właściwy w sprawach osobowych, o którym mowa w art. 32 ust. 1 ustawy o Policji, który był nim w ostatnim dniu roku kalendarzowego, w którym policjant pełnił służbę, za którą ma być przyznana nagroda roczna. Tym samym nie musi nim być obecny przełożony właściwy w sprawach osobowych policjanta, który stał się nim w roku kalendarzowym następującym po roku, za który nagroda przysługuje, na skutek zmiany przez policjanta jednostki organizacyjnej Policji, która pociągnęła za sobą zmianę przełożonego właściwego w sprawach osobowych. Policjant może bowiem pełnić służbę w różnych jednostkach Policji, a zatem podlegać różnym przełożonym, o których mowa w art. 32 ust. 1 ustawy o Policji. W takiej sytuacji, zgodnie z art. 110 ust. 12 ustawy o Policji, nagrodę roczną przyznaje się i wypłaca policjantowi w jednostce, która była w danym roku ostatnim miejscem pełnienia przez niego służby. Podmiotem uprawnionym do przyznania nagrody rocznej nie może być jednak sama jednostka policji, gdyż jest ona tylko urzędem stanowiącym aparat pomocniczy (zespół środków materialno-technicznych), za pomocą którego właściwy komendant wykonuje swoje zadania. Niemniej służba w konkretnej jednostce Policji powoduje, że policjant ma ściśle określonego przełożonego właściwego 
w sprawach osobowych. Zmiana jednostki może skutkować zmianą tego przełożonego. Wobec tego właściwy do przyznania nagrody rocznej jest ten przełożony właściwy w sprawach osobowych, który był nim w dniu 31 grudnia roku kalendarzowego, za który nagroda przysługuje.

Przyznanie nagrody rocznej następuje $\mathrm{w}$ drodze kwalifikowanego aktu administracyjnego, jakim jest decyzja administracyjna. Od takiej decyzji przysługuje policjantowi odwołanie do wyższego przełożonego (art. 110 ust. 8c ustawy o Policji), chyba że organem I instancji jest Komendant Główny Policji. Wówczas policjantowi przysługuje środek zaskarżenia w postaci wniosku o ponowne rozpatrzenie sprawy. Decyzja organu odwoławczego ma charakter ostateczny. Jest zatem wykonalna. Policjant może jednak, po wyczerpaniu środków zaskarżenia, złożyć skargę do sądu administracyjnego, zgodnie z art. 52 § 1 Ustawy z dnia 30 sierpnia 2002 r. Prawo o postępowaniu przed sądami administracyjnymi ${ }^{17}$ (oczywiście przy uwzględnieniu art. $52 \S 2$ i 3 p.p.s.a.). Wobec tego należy się zgodzić ze stanowiskiem NSA wyrażonym w wyroku z dnia 5 stycznia $2017 \mathrm{r}^{18}{ }^{18}$,że tylko forma decyzji administracyjnej rozstrzygającej sprawę w wymienionym zakresie umożliwia jej kontrolę zarówno instancyjna, jak i sądowoadministracyjną. Przedmiotem sprawy administracyjnej jest zatem ustalenie, czy zostały spełnione warunki do przyznania nagrody rocznej za dany rok kalendarzowy. Nagroda roczna musi mieć bowiem odniesienie do konkretnego roku kalendarzowego, bo tylko $\mathrm{w}$ ten sposób możliwe jest ustalenie minimalnego wymaganego okresu pełnionej służby, a także ustalenie innych wymogów warunkujących jej przyznanie. Przyznanie nagrody rocznej bez odniesienia do konkretnego roku kalendarzowego czyni te ustalenia niemożliwymi. Decyzja taka jest obciążona wadą kwalifikowana, co skutkuje koniecznością wyeliminowania jej z obrotu prawnego na podstawie art. $156 \S 1$ pkt 2 Ustawy z dnia 14 czerwca 1960 r. Kodeks postępowania administracyjnego ${ }^{19}$.

\section{Decyzja o obniżeniu nagrody rocznej}

Jak już wcześniej wspomniano, obniżenie nagrody rocznej ma charakter następczy w stosunku do jej przyznania, ponieważ ma sens wyłącznie w sytuacji, gdy uprzednio ustalono, że policjantowi prawo to przysługuje

\footnotetext{
${ }^{17}$ Tekst jedn. Dz.U. 2019, poz. 2325 ze zm., dalej „p.p.s.a.”.

${ }^{18}$ Wyrok NSA z 5 I 2017 r., sygn. I OSK 1934/15, Legalis nr 1722029.

19 Tekst jedn. Dz.U. 2020, poz. 256 ze zm., dalej „k.p.a.”.
} 
za konkretny rok służby. W sytuacji gdy policjant w danym roku kalendarzowym nie pełnił służby w minimalnie wskazanym w art. 110 ust. 3 ustawy o Policji wymiarze i nie zachodziły żadne okoliczności, które uprawniałyby go do nabycia tego prawa bez konieczności pełnienia służby przez co najmniej 6 miesięcy w danym roku kalendarzowym, lub gdy zostanie spełniony jeden $\mathrm{z}$ warunków, o których mowa w art. 110 ust. 7 ustawy o Policji, skutkujących tym, że nagroda ta nie przysługuje, rozstrzyganie o obniżeniu nagrody rocznej za ten rok kalendarzowy staje się bezprzedmiotowe.

Przepis art. 110 ust. 5 ustawy o Policji przewiduje cztery przypadki, które powodują obligatoryjne obniżenie nagrody rocznej. Organem zobowiązanym do obniżenia nagrody rocznej jest ten sam podmiot, który jest właściwy w sprawie jej przyznania. Istotne jest również to, że w sytuacjach objętych wymienionym przepisem pragmatyki służbowej podmioty, o których mowa w art. 110 ust. 13-15 ustawy o Policji, są zobligowane do obniżenia tej nagrody ${ }^{20}$. Świadczy o tym ta część przepisu art. 110 ust. 5 ustawy o Policji, z której wynika, że "nagrodę roczną obniża się policjantowi", a nie, że "może być ona obniżona”. Tym samym decyzja administracyjna w zakresie, w jakim rozstrzyga o obniżeniu nagrody rocznej, jeśli spełni się choćby jeden z warunków wskazanych w art. 110 ust. 5 pkt 1-4 ustawy o Policji, ma charakter związany. Ustawodawca nie pozostawił tej kwestii uznaniu uprawnionego organu administracyjnego ${ }^{21}$.

Jak wynika wprost z art. 110 ust. 9 ustawy o Policji, nagrodę roczną wypłaca się policjantowi do 31 marca roku kalendarzowego następującego po roku, za który przysługuje nagroda. Nie tylko więc przyznanie nagrody rocznej musi nastąpić w pierwszych trzech miesiącach roku kalendarzowego następującego po roku, za który przysługuje nagroda, ale także jej obniżenie. Są to czynności funkcjonalnie ze sobą związane. Mimo że następują w odpowiedniej kolejności, muszą zaistnieć łącznie.

${ }^{20}$ "W przewidzianych w art. 110 ust. 5 i 6 Ustawy z dnia 6 kwietnia 1990 roku o Policji (t.j. Dz.U. z 2002 r., Nr 7, poz. 58 ze zm.) przypadkach obniżenie nagrody rocznej jest obligatoryjne" (wyrok WSA w Szczecinie z 26 III 2009 r., sygn. II SA/Sz 93/09, Legalis nr 182827); P. Zając, Uwagi do art. 110, w: Ustawa o Policji. Komentarz, pod red. K. Chałubińskiej-Jentkiewicz, J. Kurek, Warszawa 2020.

${ }^{21}$ "Użyte w art. 110 ust. 5 pkt 2 Ustawy o Policji sformułowanie «obniża się» wskazuje na obligatoryjny charakter tego przepisu i nie pozostawia przełożonemu właściwemu w sprawach osobowych możliwości stosowania uznania administracyjnego co do samego obniżenia" (wyrok WSA w Warszawie z 21 II 2019 r., sygn. II SA/Wa 863/18, Legalis nr 2237278). 
Nie do zaakceptowania byłby pogląd, według którego przyznanie nagrody rocznej skutkowałoby przyznaniem jej w pełnej wysokości i następnie wypłata, a w dalszej kolejności konieczne byłoby jej obniżenie, wskutek czego niezbędne byłoby dochodzenie przez organ Policji nienależnej części wypłaconej nagrody rocznej albo jej potrącenie z innych świadczeń przysługujących policjantowi.

Jeżeli zatem osnowa decyzji administracyjnej wskazuje, że policjantowi przysługuje nagroda roczna za dany rok kalendarzowy, to wynika z tego, że prawo to przysługuje w pełnej wysokości za ten rok kalendarzowy. Jeśli jednak rozstrzygnięcie tej decyzji sprowadzałoby się do przyznania nagrody rocznej, a następnie do jej obniżenia, wówczas należałoby przyjąć, że organ ustalił, iż prawo do nagrody rocznej przysługuje funkcjonariuszowi za dany rok i jednocześnie, że podlega ono obniżeniu. W praktyce osnowa decyzji administracyjnej najczęściej ogranicza się do sformułowania "obniżam nagrodę roczną". $\mathrm{Z}$ faktu tego jednak wynika, że organ ustalił uprzednio, tj. przed tym obniżeniem, że prawo takie zmaterializowało się wobec policjanta za konkretny rok kalendarzowy oraz że wskutek okoliczności wymienionych w art. 110 ust. 5 ustawy o Policji podlega ono obniżeniu, a tym samym, że nie przysługuje temu funkcjonariuszowi w pełnej wysokości. $Z$ treści rozstrzygnięcia mogłoby również wynikać, że nagroda roczna jest przyznana, ale w niepełnej wysokości (np. w 50\%, 60\%, 70\% lub $80 \%$ ). Osnowa takiej decyzji mogłaby mieć treść „przyznaję nagrodę roczną w wysokości ... \%"22. Z faktu tego należałoby też wnioskować, że uprzednio ustalono, iż prawo do nagrody rocznej przysługuje policjantowi, a następnie, że ją obniżono.

Zgodnie z art. 110 ust. 6 ustawy o Policji obniżenie nagrody rocznej w sytuacjach, o których mowa w art. 110 ust. 5 ustawy o Policji, może nastąpić w granicach od 20\% do 50\%. Wysokość tego obniżenia ustawodawca pozostawił uznaniu administracyjnemu, z tym jednak zastrzeżeniem, że musi ono mieścić się w granicach wytyczonych przez art. 110 ust. 6 ustawy o Policji ${ }^{23}$. Tym samym osnowa rozstrzygnięcia o obniżeniu nagrody rocznej sprowadza się jedynie do procentowego wskazania

${ }^{22}$ Zob. wyrok WSA w Warszawie z 12 I 2016 r., sygn. II SA/Wa 1073/15, Legalis nr 1407637; wyrok WSA w Szczecinie z 21 I 2009 r., sygn. II SA/Sz 838/08, Legalis nr 188087.

${ }^{23}{ }_{\text {"W }}$ sferze uznania administracyjnego pozostawała jedynie kwestia wysokości obniżenia nagrody w przedziale pomiędzy $20 \%$ a $50 \%$ jednomiesięcznego uposażenia" (wyrok WSA w Szczecinie z 26 III 2009 r., sygn. II SA/Sz 93/09). 
wysokości obniżenia nagrody rocznej, nie zaś do określenia kwotowego tego obniżenia. Nieprawidłowe byłoby rozstrzygnięcie, w którym wskazano by kwotę, o jaką nagroda roczna byłaby pomniejszona wskutek jej obniżenia. Należałoby wówczas zweryfikować, czy kwota ta mieści się w granicach minimum i maksimum określonych przez przepis art. 110 ust. 6 ustawy o Policji. Obniżenie nagrody rocznej z naruszeniem dyspozycji wymienionej normy prawnej stanowiłoby o wadzie kwalifikowanej tej decyzji, co skutkowałoby koniecznością wyeliminowania jej z obrotu prawnego w drodze stwierdzenia jej nieważności, na podstawie art. 156 $\S 1$ pkt 2 k.p.a., jako decyzji rażąco naruszającej prawo.

Miarkowanie, w jakiej wysokości powinno nastąpić obniżenie nagrody rocznej, w granicach określonych w art. 110 ust. 6 ustawy o Policji, nie może mieć jednak charakteru dowolnego, decyzja w tym zakresie, tj. wyłącznie w zakresie ustalenia wysokości tego obniżenia, miałaby bowiem charakter dowolny i arbitralny. Organ, obniżając nagrodę roczna, powinien stosować kryteria wskazane w art. 110 ust. $8 \mathrm{~b}$ ustawy o Policji. Winien on zatem uwzględnić całokształt okoliczności sprawy, w szczególności charakter popełnionego przestępstwa, przestępstwa skarbowego lub przewinienia, jego skutki, rodzaj i wymiar orzeczonej kary oraz dotychczasowe wyniki policjanta w służbie. Jak wynika z powyższego, kryteria te nie mają wyraźnie zarysowanych granic znaczeniowych. Stanowią jednak pewne wskazówki, którymi powinien się kierować organ, określając wysokość obniżenia nagrody rocznej. Pozwalają przynajmniej na zniwelowanie skrajnego subiektywizmu oceny zdarzenia będącego źródłem lub przyczyną obniżenia nagrody rocznej. Nie budzi wątpliwości, że obniżenie nagrody rocznej musi nastąpić w przypadkach wskazanych w art. 110 ust. 5 ustawy o Policji. Wobec tego uzasadnienie samego obniżenia wynika wprost z treści normy prawnej obligującej do takiego działania przez organ. Określona w rozstrzygnięciu wysokość tego obniżenia wymaga natomiast szczegółowego uzasadnienia, które wykaże, na podstawie kryteriów wskazanych w art. 110 ust. 8b ustawy o Policji, że podjęta decyzja ma właściwe podbudowanie instrumentalne. Uzasadnienie w zakresie, o którym mowa, musi świadczyć o tym, że organ działał w graniach określonych nie tylko przez art. 110 ust. 6 ustawy o Policji, ale także art. 7 k.p.a. Policjant musi mieć z kolei przekonanie, że określona wysokość obniżenia spełnia zakładany przez ustawodawcę cel, dla którego ta instytucja została ustanowiona.

Zgodnie z art. 110 ust. 8 ustawy o Policji obniżenie prawa do nagrody rocznej następuje za rok kalendarzowy, w którym policjant popełnił 
przestępstwo lub czyn, o których mowa w art. 110 ust. 5 pkt 1 i 2, w art. 41 ust. 1 pkt 4 i 4 a oraz w art. 41 ust. 2 pkt 2 i 8 ustawy o Policji, a także w art. 134 pkt 3-7 ustawy o Policji, lub otrzymał opinię, o której mowa w art. 38 ust. 2 pkt 2 i 3 ustawy o Policji, albo został zwolniony ze służby w przypadkach, o których mowa w art. 41 ust. 1 pkt 2 i ust. 2 pkt 1 ustawy o Policji, a jeżeli nagroda została już wypłacona - za rok, w którym postępowanie karne lub dyscyplinarne $w$ tej sprawie zostało zakończone prawomocnym orzeczeniem lub policjant został zwolniony ze służby ${ }^{24}$. Ze względu na omawianą problematykę konieczne jest zatem wskazanie, że prawo do nagrody rocznej obniżane jest w sytuacji, gdy policjant popełnił czyn, o którym mowa w art. 110 ust. 5 pkt 2 ustawy o Policji, tj. czyn polegający na naruszeniu dyscypliny służbowej lub nieprzestrzeganiu zasad etyki zawodowej, stwierdzony w prawomocnie zakończonym postępowaniu dyscyplinarnym, a jeśli nagroda roczna za ten rok została już policjantowi wypłacona, wówczas obniżeniu podlega nagroda roczna za rok, w którym postępowanie dyscyplinarne zostało zakończone prawomocnym orzeczeniem lub policjant został zwolniony ze służby ${ }^{25}$.

Należy tylko zaznaczyć, że pragmatyka służbowa przewiduje odpowiedzialność dyscyplinarną za popełnienie przewinienia dyscyplinarnego, które może polegać zarówno na naruszeniu dyscypliny służbowej, jak i nieprzestrzeganiu zasad etyki zawodowej. Naruszeniem dyscypliny służbowej jest czyn policjanta polegający na zawinionym przekroczeniu uprawnień lub niewykonaniu obowiązków wynikających z przepisów

24 „Przepis art. 110 ust. 8 wprowadza generalną zasadę, wedle której następuje dla policjanta realizacja negatywnych konsekwencji finansowych w postaci obniżenia nagrody rocznej, przy czym przepis ten stanowi uzupełnienie norm zawartych w przepisie art. 110 ust. 5 i 7" (wyrok WSA w Krakowie z 23 VIII 2017 r., sygn. III SA/Kr 622/17, Legalis nr 1665440).

${ }^{25}$ Przesłanką obniżenia nagrody rocznej jest zatem dopiero prawomocne orzeczenie dyscyplinarne stwierdzające popełnienie określonego czynu. Brak w przepisach ustawy o Policji podstaw do wstrzymywania wypłaty nagrody rocznej na czas trwania postępowania dyscyplinarnego. Wprost przeciwnie, powołany wyżej przepis art. 110 ust. 8 pkt 1 przewiduje rozwiązanie sytuacji, w której data prawomocnego orzeczenia dyscyplinarnego przypada na rok późniejszy niż data czynu, w związku z którym postępowanie dyscyplinarne przeprowadzono. Z omawianych przepisów wynika wprost, że nagroda roczna jest należna policjantowi do czasu prawomocnego rozstrzygnięcia dyscyplinarnego, zaś w przypadku stwierdzenia w tym orzeczeniu naruszenia dyscypliny służbowej (lub nieprzestrzegania zasad etyki zawodowej - aut.) podlega ona obniżeniu za rok, w którym orzeczenie stało się prawomocne" (wyrok WSA w Gdańsku z 6 VI 2013 r., sygn. III SA/Gd 287/13, Legalis nr 695431). 
prawa lub rozkazów i poleceń wydanych przez przełożonych uprawnionych na podstawie tych przepisów (art. 132 ust. 2 ustawy o Policji). Przykładowy katalog czynów polegających na naruszeniu dyscypliny służbowej określa art. 132 ust. 3 ustawy o Policji. Nie ma on charakteru wyczerpującego (numerus clausus). Stanowi pewną egzemplifikację najbardziej typowych sytuacji, które wyczerpują znamiona naruszenia dyscypliny służbowej. Z kolei zasady etyki zawodowej policjanta zostały określone w załączniku do zarządzenia nr 805 Komendanta Głównego Policji z dnia 31 grudnia 2003 r. w sprawie "Zasad etyki zawodowej policjanta" ${ }^{\prime 2}$. Niecelowe byłoby $w$ ramach tego opracowania szczegółowe odniesienie się do problematyki związanej z przewinieniem dyscyplinarnym, a w szczególności z różnica, jaka zachodzi pomiędzy naruszeniem dyscypliny służbowej i nieprzestrzeganiem zasad etyki zawodowej. Istotne z punktu widzenia zastosowania instytucji obniżenia nagrody rocznej jest to, że warunek, o którym mowa w art. 110 ust. 5 pkt 2 ustawy o Policji, jest spełniony już w sytuacji popełnienia przez policjanta przewinienia dyscyplinarnego polegającego na naruszeniu dyscypliny służbowej lub nieprzestrzeganiu zasad etyki zawodowej, stwierdzonego w prawomocnie zakończonym postępowaniu dyscyplinarnym. Orzeczenie to nie musi więc wymierzać kary za popełnione przewinienie dyscyplinarne. Tym samym może nim być orzeczenie, którym odstąpiono od wymierzenia kary dyscyplinarnej (art. 135j ust. 1 pkt 3 ustawy o Policji), zgodnie bowiem z art. 135j ust. 5 ustawy o Policji odstąpienie od ukarania jest możliwe, jeżeli stopień winy lub stopień szkodliwości przewinienia dyscyplinarnego nie jest znaczny dla służby, a właściwości i warunki osobiste policjanta oraz dotychczasowy przebieg służby uzasadniają przypuszczenie, że pomimo odstąpienia od ukarania będzie on przestrzegał dyscypliny służbowej i zasad etyki zawodowej. Orzeczenie takie musi zatem potwierdzać zaistnienie przewinienia dyscyplinarnego, polegającego na naruszeniu dyscypliny służbowej lub nieprzestrzeganiu zasad etyki zawodowej. Naruszenie dyscypliny służbowej lub nieprzestrzeganie zasad etyki zawodowej jest niewątpliwie stwierdzone tym orzeczeniem ${ }^{27}$. Nie może nim jednak w oczywisty sposób być ani orzeczenie o uniewinnieniu (art. 135j

${ }^{26}$ Dz.Urz. KGP 2004 Nr 1, poz. 3.

27 "Chodzi zatem o fakt naruszenia dyscypliny służbowej, który musi być wprawdzie wykazany w prawomocnie zakończonym postępowaniu dyscyplinarnym, a nie samo wymierzenie kary dyscyplinarnej" (wyrok NSA z 22 IV 2016 r., sygn. I OSK 1568/14, Legalis nr 1511001; wyrok WSA w Poznaniu z 5 X 2017 r., sygn. II SA/Po 430/17, Legalis 
ust. 1 pkt 1 ustawy o Policji), ani orzeczenie o umorzeniu postępowania dyscyplinarnego (art. 135j ust. 1 pkt 4 ustawy o Policji). W tym ostatnim przypadku przełożony dyscyplinarny umarza albo może umorzyć postępowanie dyscyplinarne w przypadkach, o których mowa w art. 135ja ust. 1 albo 2 ustawy o Policji. Umorzenie jako rozstrzygnięcie o charakterze formalnym nie odnosi się do meritum i nie rozstrzyga sprawy co do istoty.

Zgodnie z art. 110 ust. 8a ustawy o Policji okoliczności uzasadniające pozbawienie lub ograniczenie prawa do nagrody rocznej ustala się na podstawie orzeczeń i decyzji organów właściwych w sprawach karnych o przestępstwo lub przestępstwo skarbowe, w sprawach dyscyplinarnych oraz w sprawach dotyczących opiniowania policjantów, a także na podstawie dokumentacji prowadzonej w sprawach osobowych policjantów. W zakresie objętym niniejszym opracowaniem w kręgu zainteresowania pozostawać będą orzeczenia wydane w postępowaniu dyscyplinarnym, ale tylko te, które stanowią o ukaraniu albo odstąpieniu od ukarania (art. 135j ust. 1 pkt 2 albo 3 ustawy o Policji), tylko one bowiem ustalaja, czy zaistniał czyn w postaci przewinienia dyscyplinarnego polegającego na naruszeniu dyscypliny służbowej lub nieprzestrzeganiu zasad etyki zawodowej, a jeśli tak, że popełnił go indywidualnie oznaczony policjant, któremu można przypisać winę za jego popełnienie. Przepis art. 110 ust. 5 pkt 2 ustawy o Policji wymaga, aby naruszenie dyscypliny służbowej lub nieprzestrzeganie zasad etyki zawodowej stwierdzone było w prawomocnie zakończonym postępowaniu dyscyplinarnym. Tym samym przepis ten wymaga, aby rozstrzygnięcie wydane w postępowaniu dyscyplinarnym posiadało przymiot prawomocności, bo tylko takie orzeczenie podlega wykonaniu zgodnie z art. 1350 ustawy o Policji.

\section{Prawomocność orzeczenia dyscyplinarnego}

Przepis art. 135o ust. 1 pkt 1 i 2 ustawy o Policji stanowi, że orzeczenie wydane $\mathrm{w}$ postępowaniu dyscyplinarnym staje się prawomocne:

- z upływem terminu do wniesienia odwołania, wniosku o ponowne rozpatrzenie sprawy lub zażalenia, jeżeli go nie wniesiono;

- w dniu wydania orzeczenia lub postanowienia przez organ odwoławczy.

nr 1689504); w tym samym tonie wyrok WSA w Warszawie z 3 II 2015 r., sygn. II SA/ Wa 1212/14, Legalis nr 1244073. 
Wynika to z przyjętego modelu dwuinstancyjnego postępowania dyscyplinarnego ${ }^{28}$, w którym orzeczenie wydane w pierwszej instancji może zostać zaskarżone do wyższego przełożonego dyscyplinarnego ${ }^{29}$. Jak słusznie zauważa NSA w wyroku z 8 listopada 2005 r. ${ }^{30}$, „Przepisy rozdziału 10 cytowanej Ustawy o Policji, normujące odpowiedzialność dyscyplinarną i karną policjantów, stanowią podstawę prawną postępowania dyscyplinarnego i postępowania dyscyplinarnego odwoławczego, nie pozostawiając wątpliwości, że jest ono postępowaniem dwuinstancyjnym. Ustawodawca dał temu wyraz wprost w treści art. 135k. Tym samym odwołanie od orzeczenia wydanego w I instancji w przypadku tego rodzaju postępowania przenosi kompetencję do załatwienia sprawy dyscyplinarnej przez wyższego przełożonego dyscyplinarnego w jej całokształcie" ${ }^{\prime \prime}$.

Możliwość zaskarżenia zależna jest jednak od uprzedniego prawidłowego wprowadzenia do obrotu prawnego orzeczenia. Zgodnie $\mathrm{z}$ art. 135j ust. 7 ustawy o Policji orzeczenie niezwłocznie po jego wydaniu winno być doręczone ${ }^{32}$ obwinionemu, a także obrońcy obwinionego, jeśli ten ostatni takowego ustanowił (art. 135f ust. 6 ustawy o Policji ${ }^{33}$. Odwołanie może złożyć zarówno obwiniony, jak i jego obrońca. Mogą

${ }^{28}$ Szerzej na ten temat zob. Postępowanie odwoławcze w sprawach dyscyplinarnych w stużbach mundurowych, pod red. W. Kozielewicza, P. Jóźwiaka, K. Opalińskiego, Piła 2016.

${ }^{29}$ Należy jednak zastrzec, że celowo pominięto w tym miejscu regulację zawartą w art. 135fa ustawy o Policji. Obwinionemu przysługuje odwołanie od orzeczenia, o którym mowa w art. 135fa ust. 5 ustawy o Policji (art. 135fa ust. 6 ustawy o Policji). Jego wniesienie, zgodnie z art. 135fa ust. 8 ustawy o Policji, skutkuje koniecznością uchylenia orzeczenia o ukaraniu i kontynuacją postępowania w zwykłym trybie, w wyniku czego przełożony dyscyplinarny wydaje orzeczenie, o którym mowa w art. 135j ust. 1 ustawy o Policji, od którego przysługuje odwołanie w trybie art. 135k ustawy o Policji. Tym samym mimo złożenia odwołania, o którym mowa w art. 135fa ust. 6 ustawy o Policji, obwiniony ma prawo do zaskarżenia nowego orzeczenia w dyscyplinarnym toku instancji.

${ }^{30}$ Wyrok NSA z 8 XI 2005 r., sygn. I OSK 225/05, Legalis nr 1124091.

${ }^{31}$ Por. także z wyrokiem WSA we Wrocławiu z 21 III 2018 r., sygn. IV SA/Wr 70/18, Legalis nr 1746803, a także z Ł. Czebotar i in., Ustawa o Policji. Komentarz, Warszawa 2015, s. 723.

32 "Zgodnie z art. $128 \S 1$ k.p.k. stosowanym w postępowaniu dyscyplinarnym z mocy art. 135p ust. 1 ustawy o Policji - orzeczenia i zarządzenia doręcza się w uwierzytelnionych odpisach, jeżeli ustawa nakazuje ich doręczenie" (wyrok NSA z 5 VII 2017 r., sygn. I OSK 347/17, Legalis nr 1845542).

${ }^{33}$ Należy jednak dodać, że ustanowienie obrońcy jest tylko prawem, a nie obowiązkiem obwinionego (art. $135 \mathrm{f}$ ust. 1 pkt 4 a ustawy o Policji), nawet zatem ustanowienie obrońcy nie odbiera obwinionemu możliwości samodzielnego korzystania z posiadanych uprawnień w ramach prowadzonego postępowania dyscyplinarnego. 
oni tego dokonać niezależnie od siebie, ponieważ ustawa nie wymaga współdziałania pomiędzy nimi w tym zakresie ${ }^{34}$. Termin do wniesienia odwołania, w sytuacji doręczenia orzeczenia zarówno obwinionemu, jak i jego obrońcy, liczy się od dnia doręczenia, które nastąpiło wcześniej (art. 135 f ust. 6 in fine ustawy o Policji) ${ }^{35}$. Odwołanie może zostać wniesione w terminie 7 dni od dnia skutecznego doręczenia orzeczenia i ma charakter zawity (art. 135k ust. 1 ustawy o Policji). Wniesienie odwołania po upływie tego terminu jest bezskuteczne ${ }^{36}$. Wyższy przełożony dyscyplinarny odmawia bowiem przyjęcia odwołania w drodze postanowienia, jeżeli zostało wniesione po terminie lub przez osobę nieuprawnioną albo jest niedopuszczalne. Postanowienie w tej sprawie jest ostateczne (art. 135k ust. 3 ustawy o Policji). Odwołanie składa się natomiast do wyższego przełożonego dyscyplinarnego za pośrednictwem przełożonego, który wydał orzeczenie w pierwszej instancji (art. 135k ust. 2 ustawy o Policji).

Wyjątek stanowią orzeczenia wydane przez ministra właściwego do spraw wewnętrznych lub Komendanta Głównego Policji. Od nich nie przysługuje odwołanie, ale wniosek o ponowne rozpatrzenie sprawy. Do wniosku tego stosuje się jednak odpowiednio przepisy dotyczące odwołań od orzeczeń (art. 135k ust. 4 ustawy o Policji).

Na marginesie należy wskazać, że pragmatyka służbowa nie uregulowała w sposób odrębny kwestii związanej z doręczeniem orzeczeń. Dlatego też w tym zakresie należy stosować przepisy procedury karnej. Jak bowiem wynika wprost $\mathrm{z}$ art. 135p ust. 1 ustawy o Policji, w zakresie nieuregulowanym w ustawie o Policji do postępowania dyscyplinarnego stosuje się odpowiednio przepisy Ustawy z dnia 6 czerwca 1997 r. Kodeks postępowania karnego ${ }^{37}$, dotyczące porządku czynności procesowych, z wyjątkiem art. 117 i art. 117a, wezwań, terminów, doręczeń

34 "Nie stanowi przeszkody do skutecznego wniesienia odwołania regulacja zawarta w przepisie art. 135f ust. 6 Ustawy z 6 kwietnia 1990 r. o Policji (t.j. Dz.U. z 2015 r. poz. 355). Z postanowień powołanego przepisu wynika powinność współdziałania obwinionego i obrońcy w razie doręczenia każdemu z nich pisma w odmiennych terminach. Tym samym brak jest podstaw do przyjęcia, aby konieczność współdziałania obwinionego i obrońcy stanowiła przeszkodę do wniesienia środka odwoławczego" (wyrok NSA z 8 X 2014 r., sygn. I OSK 1637/13, Legalis nr 1087064).

35 "…] termin do wniesienia odwołania otwiera się tylko jeden raz, zarówno dla obwinionego, jak i jego obrońcy" (wyrok WSA w Warszawie z 4 IV 2017 r., sygn. II SA/ Wa 2028/16, Legalis nr 1603327; zob. też wyrok WSA w Warszawie z 18 V 2017 r., sygn. II SA/Wa 2153/16, Legalis nr 1631124).

${ }^{36}$ Wyrok NSA z 22 II 2018 r., sygn. I OSK 826/16, Legalis nr 1788134.

${ }^{37}$ Tekst jedn. Dz.U. 2020, poz. 30 ze zm. 
i świadków, z wyłączeniem możliwości nakładania kar porządkowych oraz konfrontacji, okazania, oględzin i eksperymentu procesowego ${ }^{38}$.

Upływ terminu do wniesienia odwołania od orzeczenia wydanego $\mathrm{w}$ pierwszej instancji powoduje jego uprawomocnienie się. Wyższy przełożony dyscyplinarny zobligowany jest do odmowy jego przyjęcia, zgodnie $z$ art. 135k ust. 3 ustawy o Policji. Oznacza to, że nie przysługuje już od niego żaden środek zaskarżenia ${ }^{39}$. Tym samym wniesienie odwołania po upływie wskazanego w pragmatyce służbowej terminu jest nieskuteczne, a stwierdza to postanowienie o odmowie jego przyjęcia. Postanowienie to ma charakter deklaratoryjny ${ }^{40}$. Wobec tego orzeczenie wydane $w$ pierwszej instancji staje się prawomocne $\mathrm{z}$ chwilą upływu terminu do wniesienia odwołania, a nie w dniu wydania postanowienia o odmowie jego przyjęcia. Analogicznie jest w sytuacji złożenia wniosku o ponowne rozpatrzenie sprawy. Minister właściwy do spraw wewnętrznych lub Komendant Główny Policji wydaje postanowienie o odmowie jego przyjęcia w przypadkach wskazanych $\mathrm{w}$ art. $135 \mathrm{k}$ ust. 3 ustawy o Policji, gdyż do wniosku tego, zgodnie z art. 135k ust. 4 ustawy o Policji, stosuje się odpowiednio przepisy dotyczące odwołań od orzeczeń.

Uzyskanie przymiotu prawomocności przez orzeczenie wydane $\mathrm{w}$ postępowaniu dyscyplinarnym w pierwszej instancji wymaga zatem spełnienia łącznie dwóch przesłanek. Po pierwsze, orzeczenie musi być prawidłowo wprowadzone do obrotu, tj. doręczone uprawnionemu podmiotowi. Po drugie, musi upłynąć termin do wniesienia środka zaskarżenia w postaci odwołania albo wniosku o ponowne rozpatrzenie sprawy. Złożenie środka zaskarżenia w ustawowym terminie inicjuje postępowanie odwoławcze, $\mathrm{w}$ toku którego wyższy przełożony (minister właściwy do spraw wewnętrznych lub Komendant Główny Policji) wydaje nowe orzeczenie, którym albo utrzymuje w mocy orzeczenie pierwszej instancji, albo uchyla je w całości lub w części, i w tym zakresie uniewinnia obwinionego, odstępuje od jego ukarania, względnie wymierza inną karę dyscyplinarną albo umarza postępowanie, bądź

${ }^{38}$ Zagadnienie to przekracza ramy niniejszego opracowania. Szerzej na ten temat zob. P. Jóźwiak, Stosowanie prawa karnego materialnego i procesowego w postępowaniu dyscyplinarnym, w: Odpowiedzialność dyscyplinarna w Policji, pod red. P. Jóźwiaka, W.S. Majchrowicza, Piła 2011, s. 17 i n.

${ }^{39}$ Ł. Czebotar i in., op. cit., s. 724; A. Warmiński, Dyscyplinarne postępowania funkcjonariuszy Policji, Warszawa 2019, s. 64.

${ }^{40}$ Wyrok WSA w Szczecinie z 14 VI 2017 r., sygn. II SA/Sz 480/17, Legalis nr 1653474. 
uchylając to orzeczenie - umarza postępowanie dyscyplinarne w pierwszej instancji, albo uchyla orzeczenie w całości i przekazuje sprawę do ponownego rozpatrzenia przez przełożonego dyscyplinarnego, gdy rozstrzygnięcie sprawy wymaga przeprowadzenia czynności dowodowych w całości lub w znacznej części (art. 135n ust. 4 pkt 1-3 ustawy o Policji). Orzeczenie wydane po przeprowadzeniu postępowania odwoławczego staje się prawomocne $\mathrm{z}$ chwila jego wydania.

Konkludując to, co zostało wyżej powiedziane, konieczne jest zaznaczenie, że prawomocność orzeczenia zależna jest od różnych okoliczności, a także od tego, czy orzeczenie zostało wydane w pierwszej instancji czy też w wyniku wniesionego środka zaskarżenia, tj. odwołania albo wniosku o ponowne rozpatrzenie sprawy. Jeśli orzeczenie jest wydane w pierwszej instancji, to staje się prawomocne $\mathrm{z}$ upływem terminu do wniesienia odwołania lub wniosku o ponowne rozpatrzenie sprawy, jeżeli go nie wniesiono (art. 135o ust. 1 pkt 1 ustawy o Policji). Jeśli natomiast jest orzeczeniem wydanym $\mathrm{w}$ wyniku wniesionego odwołania, staje się prawomocne $\mathrm{w}$ dniu wydania orzeczenia przez organ odwoławczy (art. 135o ust. 1 pkt 2 ustawy o Policji).

Prawomocne orzeczenie podlega wykonaniu, pomimo że zgodnie $\mathrm{z}$ art. 138 ustawy o Policji od orzeczenia kończącego postępowanie dyscyplinarne policjantowi przysługuje prawo wniesienia skargi do sądu administracyjnego. Przez orzeczenie kończące postępowanie dyscyplinarne należy rozumieć każde orzeczenie wydane przez wyższego przełożonego dyscyplinarnego w trybie art. 135n ustawy o Policji ${ }^{41}$, a zatem każde orzeczenie wydane $\mathrm{w}$ drugiej instancji ${ }^{42}$. Istotne jest również to, że prawomocność orzeczenia dotyczy wyłącznie kwestii związanych z jego skutkami w dyscyplinarnym toku instancji. Nie ma natomiast odniesienia do postępowania sądowo-administracyjnego, gdyby bowiem przyjąć odmienne założenie, należałoby też uznać, że od prawomocnego orzeczenia w ogóle nie przysługuje prawo skargi do sądu administracyjnego, który byłby związany takim prawomocnym orzeczeniem $^{43}$.

Ustawa o Policji nie posługuje się $\mathrm{w}$ odniesieniu do orzeczeń wydanych $\mathrm{w}$ postępowaniu dyscyplinarnym takim pojęciem jak

\footnotetext{
${ }^{41}$ Postanowienie NSA z 7 IX 2011 r., sygn. I OZ 641/11, Legalis nr 638321.

${ }^{42}$ Postanowienie NSA z 26 IX 2014 r., sygn. I OSK 2252/14, Legalis nr 1070552; postanowienie NSA z 26 IX 2014 r., sygn. I OSK 2251/14, Legalis nr 1070545.

${ }^{43}$ Wyrok NSA z 6 III 2018 r., sygn. I OSK 2836/17, Legalis nr 1788603.
} 
"ostatecznośćc 44 , jak to ma miejsce w postępowaniu administracyjnym w odniesieniu do decyzji administracyjnej (np. art. 16 czy art. 269 k.p.a. $)^{45}$. Należy jednak podzielić stanowisko doktryny, według którego prawomocność orzeczenia wydanego w postępowaniu dyscyplinarnym jest odpowiednikiem ostateczności decyzji w rozumieniu przepisów procedury administracyjnej ${ }^{46}$.

Skarga do sądu administracyjnego jest dopuszczalna wyłącznie po wyczerpaniu środków zaskarżenia, jeżeli służyły one skarżącemu w postępowaniu przed organem właściwym w sprawie, zgodnie z art. $52 \S 1$ p.p.s.a. Z kolei przepisy art. $52 \S 2$ i 3 p.p.s.a. wskazuja, jak rozumieć pojęcie „wyczerpanie środków zaskarżenia”, które warunkuje dopuszczalność wniesienia skargi do sądu administracyjnego. Tym samym nawet wniesienie takiej skargi nie pozbawia danego orzeczenia dyscyplinarnego przymiotu prawomocności. Prawomocne orzeczenie podlega więc wykonaniu jeszcze przed tym, jak uprawniony złoży taką skargę, bo termin do jej złożenia biegnie od dnia doręczenia uprawnionemu prawomocnego orzeczenia i wynosi $30 \mathrm{dni}$ od tego dnia (art. $53 \S 1$ p.p.s.a.), natomiast przymiot prawomocności orzeczenie uzyskuje z chwilą jego wydania przez organ odwoławczy. Należy tylko dodać, że przepisy p.p.s.a. warunkują możliwość złożenia skargi do sądu administracyjnego od uprzedniego wyczerpania toku instancyjnego przewidzianego przez przepisy pragmatyki służbowej. Orzeczenie wydane w pierwszej instancji, które zostało prawidłowo wprowadzone do obrotu prawnego, co do którego nie wniesiono odwołania w ustawowym terminie, staje się zatem prawomocne i nie przysługuje od niego prawo do wniesienia skargi do sądu administracyjnego. Orzeczenie takie jest również wykonalne.

Warto ponadto zaznaczyć, że samo wznowienie postępowania dyscyplinarnego, na zasadach i w trybie określonym w art. 135r i n. ustawy o Policji, także nie skutkuje ipso facto utratą przez kwestionowane orzeczenie, którym stwierdzono naruszenie dyscypliny służbowej lub nieprzestrzeganie zasad etyki zawodowej, przymiotu prawomocności.

${ }^{44}$ Należy tylko zaznaczyć, że art. 135fa ust. 7 i art. 135k ust. 3 ustawy o Policji posługuje się pojęciem "ostateczność", ale odnosi go wyłącznie do postanowienia o odmowie przyjęcia odwołania.

${ }^{45}$ Przeciwnie - B. Opaliński, M. Rogalski, P. Szustakiewicz, Uwagi do art. 135o, w: Ustawa o Policji. Komentarz, Warszawa 2015; B. Opaliński, P. Szustakiewicz, Policja. Studium administracyjnoprawne, Warszawa 2013, s. 179.

${ }^{46}$ W. Maciejko, A. Korcz-Maciejko, op. cit., s. 294. 
Posiada ono ten przymiot i funkcjonuje w obrocie prawnym do czasu wydania prawomocnego orzeczenia w postępowaniu wznowieniowym o jego uchyleniu. $Z$ oczywistych względów orzeczenie odmawiające uchylenia dotychczasowego orzeczenia, o którym mowa w art. 135s ust. 1 pkt 3 ustawy o Policji, nie może zmienić dotychczasowego status $q u o$. Orzeczenie wydane w postępowaniu wznowieniowym uchylające dotychczasowe orzeczenie i stwierdzające uniewinnienie ukaranego lub umorzenie postępowania dyscyplinarnego (art. 135s ust. 1 pkt 1 ustawy o Policji) nie tylko pozbawia to orzeczenie przymiotu prawomocności, ale definitywnie eliminuje je z obrotu prawnego. Tym samym orzeczenie takie może stać się podstawą do wznowienia postępowania w sprawie obniżenia nagrody rocznej na podstawie art. $145 \S 1$ pkt 8 k.p.a. Orzeczenie zmieniające dotychczasowe orzeczenie i wymierzające inną karę dyscyplinarną (art. 135s ust. 1 pkt 2 ustawy o Policji) także pozbawia dotychczasowe orzeczenie przymiotu prawomocności, zastępuje je bowiem nowym, które stwierdza popełnienie przewinienia dyscyplinarnego polegającego na naruszeniu dyscypliny służbowej lub nieprzestrzeganiu zasad etyki zawodowej, ale zasadne jest stwierdzenie, że nie może prowadzić do uchylenia ostatecznej decyzji w sprawie obniżenia nagrody rocznej wskutek wznowienia postępowania administracyjnego na podstawie art. $145 \S 1$ pkt 8 k.p.a., gdyż zgodnie z art. $146 \S 2$ k.p.a. nie uchyla się decyzji, jeżeli w wyniku wznowienia postępowania mogłaby zapaść wyłącznie decyzja odpowiadająca w swej istocie decyzji dotychczasowej. Skoro po przeprowadzeniu postępowania wznowieniowego nastąpiłaby zmiana orzeczenia stwierdzającego popełnienie przewinienia dyscyplinarnego polegającego na naruszeniu dyscypliny służbowej lub nieprzestrzeganiu zasad etyki zawodowej i wymierzono by inną karę dyscyplinarna, to takie orzeczenie niewątpliwie stwierdzałoby również popełnienie przewinienia dyscyplinarnego polegającego na naruszeniu dyscypliny służbowej lub nieprzestrzeganiu zasad etyki zawodowej. Tym samym, mimo zmiany orzeczenia, nadal spełniony byłby warunek, o którym mowa w art. 110 ust. 5 pkt 2 ustawy o Policji.

\section{Podsumowanie}

Służba w Policji to szczególny rodzaj niepracowniczego zatrudnienia, z którym wiążą się ograniczenia nieznane innym grupom zawodowym, których podstawą zatrudnienia jest stosunek pracy. Ograniczenia te 
rekompensowane są wieloma przywilejami ustanowionymi w pragmatyce służbowej. Jednym $\mathrm{z}$ nich jest prawo policjanta do nagrody rocznej. Ma ono charakter motywacyjny, stanowi bowiem dodatkowe przysporzenie dla funkcjonariusza i jest dodatkową gratyfikacją za służbę pełnioną $w$ danym roku kalendarzowym. W ustawie o Policji zostały ustanowione określone przesłanki warunkujące nabycie prawa do nagrody rocznej, a także przesłanki skutkujące koniecznością jej nieprzyznania albo obniżenia.

Te ostatnie zostały usystematyzowane w art. 110 ust. 5 ustawy o Policji. W opracowaniu zawężono rozważania wyłącznie do jednej przesłanki określonej w treści art. 110 ust. 5 pkt 2 ustawy o Policji. Istotne z punktu widzenia tej problematyki jest to, że zarówno przyznanie, jak i obniżenie nagrody rocznej następuje w formie kwalifikowanego aktu administracyjnego, tj. decyzji administracyjnej. Zmaterializowanie się przesłanki określonej w art. 110 ust. 5 pkt 2 Ustawy o Policji wymaga jednak uprzedniego ustalenia, że policjant, któremu taka nagroda miałaby zostać przyznana, popełnił czyn stanowiący naruszenie dyscypliny służbowej lub nieprzestrzeganie zasad etyki zawodowej, który został stwierdzony w prawomocnie zakończonym postępowaniu dyscyplinarnym. Tym samym obniżenie nagrody rocznej zależne jest od rozstrzygnięcia wydanego w odrębnym postępowaniu. Prawomocne orzeczenie dyscyplinarne, stwierdzające popełnienie przewinienia dyscyplinarnego naruszenia przez policjanta dyscypliny służbowej lub nieprzestrzegania zasad etyki zawodowej, stanowi zatem jedyną okoliczność wymagającą ustalenia $\mathrm{w}$ ramach postępowania administracyjnego $\mathrm{w}$ przedmiocie obniżenia nagrody rocznej, w kontekście możliwości podjęcia decyzji merytorycznej o obniżeniu tej nagrody. Należy także dodać, że organ prowadzący postępowanie administracyjne w tej sprawie związany jest rozstrzygnięciem wydanym w postępowaniu dyscyplinarnym i nie może dokonywać własnych ustaleń w tym zakresie. Musi przyjać za udowodnione to, co tym prawomocnym orzeczeniem zostało stwierdzone, tj. że zostało popełnione przewinienie dyscyplinarne polegające na naruszeniu dyscypliny służbowej lub nieprzestrzeganiu zasad etyki zawodowej. Dokonywanie samodzielnych ustaleń przez organ administracyjny w toku postępowania administracyjnego, które stałyby w opozycji do ustaleń przełożonego dyscyplinarnego i ucieleśnionych w prawomocnym orzeczeniu, stanowiłoby o nieuprawnionym wkroczeniu organu administracyjnego w kompetencje przełożonego dyscyplinarnego. Oczywiście policjant może dowodzić, że czyn nie wypełnia 
znamion przewinienia dyscyplinarnego polegającego na naruszeniu dyscypliny służbowej lub nieprzestrzeganiu zasad etyki zawodowej, ale musi to czynić wyłącznie w ramach postępowania dyscyplinarnego. Prawomocne orzeczenie wydane w postępowaniu dyscyplinarnym jest tego rodzaju rozstrzygnięciem, które stanowi oparcie dla późniejszej decyzji o obniżeniu nagrody rocznej. Tym samym badanie, czy istnieją przesłanki do obniżenia nagrody rocznej, sprowadza się wyłącznie do ustalenia, czy w obrocie prawnym funkcjonuje takie orzeczenie. Tylko ta okoliczność jest relewantna z punktu widzenia możliwości podjęcia decyzji o obniżeniu nagrody rocznej. W tym zakresie decyzja organu administracyjnego ma charakter związany.

W sytuacji natomiast ustalenia podstaw do obniżenia nagrody rocznej organ administracyjny musi określić wysokość tego obniżenia. Dokonuje tego w granicach wytyczonych przez przepis art. 110 ust. 6 ustawy o Policji, biorąc pod uwagę wytyczne zamieszczone w art. 110 ust. $8 \mathrm{~b}$ ustawy o Policji. Ich uwzględnienie i odzwierciedlenie w uzasadnieniu decyzji administracyjnej stanowi świadectwo tego, że podjęte rozstrzygnięcie (decyzja personalna w stosunku do konkretnego funkcjonariusza) w zakresie, w jakim określa wysokość obniżenia nagrody rocznej, ma charakter uznaniowy, nie zaś arbitralny i dowolny.

Jak wskazano wyżej, instytucja obniżenia nagrody rocznej ma charakter złożony i wieloetapowy. Prawidłowość wydanej decyzji w tym przedmiocie zależna jest od innego rozstrzygnięcia, które musi funkcjonować w obrocie prawnym i musi mu przysługiwać przymiot prawomocności. Z kolei rozstrzygnięcie mające postać decyzji administracyjnej stanowi dostateczną gwarancję zabezpieczenia praw funkcjonariusza, którego ona dotyczy. Może on nie tylko kwestionować zasadność jej wydania w administracyjnym toku instancji, ale również, po jej wyczerpaniu, na drodze sądowoadministracyjnej.

Tym samym należy ocenić, że przyjęta przez ustawodawcę konstrukcja, o której mowa, stanowi optymalne rozwiązanie, które równoważy zarówno interes społeczny (interes służby), jak i partykularny interes funkcjonariusza. Instytucja nagrody rocznej pozwala oddziaływać motywująco na policjantów, nagradzając za rzeczywiście świadczoną, pełnioną przez nich służbę, poprzez przyznanie nagrody rocznej. Jej obniżenie działa natomiast represyjnie w sytuacjach, gdy policjant dopuszcza się przewinienia dyscyplinarnego polegającego na naruszeniu dyscypliny służbowej lub nieprzestrzeganiu zasad etyki zawodowej. Instrument prawny umożliwiający obniżenie nagrody rocznej w przypadku, 
o którym mowa w art. 110 ust. 5 pkt 2 ustawy o Policji, stanowi jednak przede wszystkim środek o charakterze prewencyjnym, który winien powstrzymywać funkcjonariuszy przed popełnianiem przewinień dyscyplinarnych. Policjant ponosi bowiem odpowiedzialność o charakterze dyscyplinarnym, a ponadto konsekwencje takiego czynu mają swoje odzwierciedlenie w jego sferze finansowej.

\section{REDUCTION OF THE ANNUAL AWARD FOR A POLICE OFFICER IN THE CASE OF COMMITTING A DISCIPLINARY OFFENCE ESTABLISHED IN THE FINAL RULING OF DISCIPLINARY PROCEEDINGS}

\section{S u m mary}

Public service is characterized by a number of restrictions. A police officer must submit to a special type of regime resulting from the character of the service he performs. He is obliged to perform binding orders and service commands issued by his superior. Non-performance or improper performance of orders and service commands may cause consequences of a service nature, i.e. disciplinary liability. Establishing during disciplinary proceedings that a police officer has violated service discipline or has not followed the rules of professional ethics may result in them being subjected to disciplinary punishment. However, there are also other consequences that may cause a violation of service discipline or non-compliance with the rules of professional ethics confirmed in the final ruling of disciplinary proceedings. One of these is the necessity of reducing the annual award given to a police officer.

This paper is entirely devoted to the issues related to the legal structure of reducing the annual award based on Art. 110 (5) (2) Act on the Police. This issue is of significant importance for Police authorities obliged to apply the legal provisions of service pragmatics as well as for police officers themselves because causes consequences in the financial sphere of a police officer. Violation of service discipline established in the final ruling of disciplinary proceedings is the most common reason for the need to reduce a police officer's annual award. The application of this legal institution requires establishing that the final ruling of disciplinary proceedings confirming the violation of service discipline or non-compliance with the rules of professional ethics by a police officer exists in legal circulation. Attention is focused on the prerequisite of reducing the annual award. It is also indicated which entity is obliged to issue a decision on reducing the annual award, and procedural issues related to this institution are discussed. Discussion of this matter is preceded by a discussion of the issues related to the institution of the annual award, because such a reduction may only take place if a police officer previously obtained a right to this award.

Keywords: Police - Police officer - service relationship - administrative decision annual reward 


\section{LITERATURA}

Czebotar Ł. i in., Ustawa o Policji. Komentarz, Warszawa 2015.

Gacek P., Nawiazanie stosunku stużbowego z funkcjonariuszem Policji, „Administracja: Teoria, Dydaktyka, Praktyka" 2011, nr 2(23).

Gacek P., Odwołanie od rozkazu personalnego, „Przegląd Policyjny” 2016, nr 3(123). Hanausek T., Ustawa o Policji. Komentarz, Kraków 1996.

Hanausek T. i in., Prawo Policyjne. Komentarz, t. 1, pod red. S. Sagana, Katowice 1992. Jóźwiak P., Stosowanie prawa karnego materialnego i procesowego w postępowaniu dyscyplinarnym, w: Odpowiedzialność dyscyplinarna w Policji, pod red. P. Jóźwiaka, W.S. Majchrowicza, Piła 2011.

Kacprzak J., Stosunki stużbowe w formacjach zmilitaryzowanych - charakter prawny, ochrona sądowa, "Przegląd Policyjny” 1994, nr 1(33).

Kotowski W., Ustawa o Policji. Komentarz, Warszawa 2008.

Liwo M., Status stużb mundurowych i funkcjonariuszy w nich zatrudnionych, Warszawa 2013.

Maciejko W., Osobowe prawo administracyjne, Warszawa 2008.

Maciejko W., Korcz-Maciejko A., Postepowanie w sprawach osobowych w Policji, Wrocław 2010.

Maciejko W., Rojewski M., Suławko-Karetko A., Prawo administracyjne. Zarys wykładu części szczególnej, Warszawa 2011.

Opaliński B., Uwagi do art. 27, w: B. Opaliński, M. Rogalski, P. Szustakiewicz, Ustawa o Policji. Komentarz, wyd. 2, Warszawa 2020.

Opaliński B., Rogalski M., Szustakiewicz P., Uwagi do art. 110, w: Ustawa o Policji. Komentarz, Warszawa 2015.

Opaliński B., Rogalski M., Szustakiewicz P., Ustawa o Policji. Komentarz, Warszawa 2015.

Opaliński B., Szustakiewicz P., Policja. Studium administracyjnoprawne, Warszawa 2013.

Postępowanie odwoławcze w sprawach dyscyplinarnych w stużbach mundurowych, pod red. W. Kozielewicza, P. Jóźwiaka, K. Opalińskiego, Piła 2016.

Sierocka I., Nagrody roczne funkcjonariuszy Policji, "Monitor Prawa Pracy” 2012, nr 3.

Szankin T., Stużba w Policji, w: Prawo policyjne, pod red. M. Czuryk, M. Karpiuka, J. Kostrubieca, K. Orzeszyna, Warszawa 2014.

Szustakiewicz P., Istota stosunku służbowego, w: W. Maciejko, P. Szustakiewicz, Stosunek stużbowy w formacjach mundurowych, Legalis 2016.

Szustakiewicz P., Stosunki stużbowe funkcjonariuszy stużb mundurowych $i \dot{z}$ otnierzy zawodowych jako sprawa administracyjna, Warszawa 2012.

Warmiński A., Dyscyplinarne postępowania funkcjonariuszy Policji, Warszawa 2019.

Wieczorek M., Charakter prawny stosunków służbowych funkcjonariuszy stużb mundurowych, Torun 2017.

Zając P., Uwagi do art. 110, w: Ustawa o Policji. Komentarz, pod red. K. Chałubińskiej-Jentkiewicz, J. Kurek, Warszawa 2020.

Zieliński T., Stosunek prawa pracy do prawa administracyjnego, Warszawa 1977. 